Katarzyna Zawalińska,

Zofia Śliwowska, Jan Caliński, Katarzyna Droździel, Anna Michalska

\title{
Polska wieś wobec wyzwań rozwoju społeczno-gospodarczego w XXI wieku w świetle badań IRWiR PAN w roku 2014 i 2015
}

Streszczenie: Niniejszy artykuł przedstawia najważniejsze wnioski z badań statutowych pracowników IRWiR PAN realizowanych w latach 2014-2015. Prowadzone analizy dotyczą kluczowych procesów gospodarczych i społecznych zachodzących na obszarach wiejskich w ostatnich dekadach. Artykuł obejmuje wybrane wnioski na temat: struktury obszarowej sektora gospodarstw indywidualnych, przemiany struktur demograficznych, wiejskiego rynku pracy, rozwoju przestrzennego obszarów wiejskich, przeobrażeń społecznych oraz rozwoju instytucjonalnego i organizacyjnego na wsi. Ważnym obszarem badawczym podejmowanym w IRWiR PAN jest także ocena wspólnej polityki rolnej oraz porównanie jej z politykami innych krajów w tym Farm Bill w USA.

Słowa kluczowe: obszary wiejskie, rozwój społeczno-gospodarczy, struktura agrarna, ludność wiejska, wiejski rynek pracy, rozwój przestrzenny, wspólna polityka rolna, Farm Bill.

\section{Wstęp}

Badania podejmowane w Instytucie Rozwoju Wsi i Rolnictwa Polskiej Akademii Nauk dotyczą przemian społecznych i gospodarczych na obszarach wiejskich z uwzględnieniem trendów krajowych i globalnych. Celem badań jest zarówno diagnozowanie procesów zachodzących na wsi i w rolnictwie, jak i prognozowanie przyszłych kierunków zmian oraz opracowywanie scenariuszy rozwoju.

Autorzy są pracownikami Instytutu Rozwoju Wsi i Rolnictwa PAN, ul. Nowy Świat 72, 00-330 Warszawa (Katarzyna Zawalińska, e-mail: kzawalinska@irwirpan.waw.pl; Zofia Śliwowska, e-mail: zsliwowska@irwirpan.waw.pl; Jan Caliński, e-mail: jcalinski@irwirpan.waw.pl; Katarzyna Droździel, e-mail: kdrozdziel@ irwirpan.waw.pl; Anna Michalska, e-mail: anna.michalska@irwirpan.waw.pl). 
Niniejszy artykuł przedstawia najważniejsze wnioski z badań statutowych realizowanych w instytucie w latach 2014-2015. Wybrane wnioski dotyczą: przemian struktury agrarnej i struktur demograficznych, rozwoju wiejskiego rynku pracy, rozwoju przestrzennego obszarów wiejskich, przeobrażeń społecznych polskiej wsi oraz rozwoju instytucjonalnego i organizacyjnego na wsi. Ważnym obszarem badawczym podejmowanym w IRWiR PAN jest także polityka rozwoju obszarów wiejskich i wspólna polityka rolna oraz porównanie jej z Farm Bill w USA.

\section{Zmiany struktury agrarnej}

Badania prowadzone przez Włodzimierza Dzuna (Dzun 2014a, b; Dzun 2015a, b, c; Dzun 2016) pokazują, że likwidacja PGR i utworzenie Zasobu Własności Rolnej Skarbu Państwa nie doprowadziły do zakładanego celu poprawy struktury obszarowej sektora gospodarstw indywidualnych ani umocnienia rodzinnych gospodarstw rolnych. W warunkach $\mathrm{z}$ jednej strony bardzo małego popytu na nieruchomości rolne zgromadzone w Zasobie WRSP ze strony gospodarstw indywidualnych i braku chętnych rolników na tworzenie od podstaw gospodarstw rodzinnych, a z drugiej strony zadekretowania w Ustawie, że Agencja Własności Rolnej Skarbu Państwa będzie jednostką samofinansującą się, podstawowym celem Agencji stała się sprzedaż i dzierżawa nieruchomości zgromadzonych w Zasobie WRSP w celu uzyskania środków na prowadzenie własnej działalności, w tym na utrzymanie niegenerujących dochodów nieruchomości pozostających w Zasobie. W efekcie zakup nieruchomości rolnych, szczególnie średnich i większych obszarowo, realizowali w większości inwestorzy rozporządzający odpowiednim kapitałem, w znacznej części spoza rolnictwa, których celem nie było tworzenie gospodarstw rodzinnych. Natomiast dzierżawę większych nieruchomości podejmowali podobni inwestorzy i pracownicy likwidowanych PGR, dla których był to jedyny sposób utrzymania miejsc pracy. Udział rolników indywidualnych w rozdysponowywaniu Zasobu był zdecydowanie mniejszy niż zakładano.

Najbardziej spektakularnym efektem „pierwotnego" rozdysponowania Zasobu WRSP było powstanie nowej dużej grupy wielkoobszarowych gospodarstw osób fizycznych (3364 gospodarstw powyżej 100 ha UR, w tym 637 powyżej 500 ha, użytkujących odpowiednio 1125 tys. ha UR i 544 tys. ha UR) oraz prywatnych osób prawnych, poza spółdzielczymi (1370 gospodarstw użytkujących nieco ponad $1 \mathrm{mln}$ ha UR). Z kolei w strukturze gospodarstw indywidualnych wyraźnie zarysowała się polaryzacja. Znacząco wzrosła liczba gospodarstw najmniejszych obszarowo (do 2 ha) i gospodarstw większych obszarowo (w grupie 15-100 ha wzrost liczby o $31 \%$ i powierzchni UR w ich użytkowaniu o $45 \%$ ). W rezultacie średni obszar gospodarstwa w grupie gospodarstw powyżej 1 ha (ale do 100 ha) wzrósł w skali 
kraju tylko z 6,3 ha w 1990 r. do 6,4 ha w 1996 r. podczas gdy w latach $1980-1990$ $\mathrm{w}$ tak liczonej grupie gospodarstw wzrósł z 5,7 ha do 6,3 ha.

Jak wykazały badania Wiesława Musiała (Musiał, Płonka, Wojewodzic 2015; Musiał, Wojewodzic 2015), na obszarach o rozdrobnionej strukturze agrarnej, w tym zwłaszcza w południowej i południowo-wschodniej Polsce, w ostatnich latach następuje silna polaryzacja $w$ zakresie stanu i rozwoju gospodarstw indywidualnych. Wzmocnieniu uległa niewielka liczebnie grupa gospodarstw relatywnie większych, które z reguły prowadzą bardziej intensywną produkcję rolniczą i, korzystając ze środków pomocowych UE, rozwijają majątek produkcyjny. Jednak w gminach stosunek ilościowy gospodarstw upadających do rozwojowych zbliża się do relacji 3: 1. Oznacza to, że w najbliższych latach, w związku z nasilaniem się wypadania gospodarstw z produkcji rolnej, może znacząco zwiększyć się podaż ziemi rolniczej. O jej skutecznym przepływie w dużej mierze będą decydować jednak uwarunkowania ekonomiczne i prawne, $w$ tym podatkowe, skłaniające do rozwoju produkcji rolniczej i produkcyjnego zagospodarowania ziemi, zwłaszcza o dużym potencjale produkcyjnym.

Aby poprawić strukturę agrarną $\mathrm{w}$ rolnictwie, potrzebne są nowe rozwiązania służące konsolidacji ziemi, np. poprzez pasterskie systemy zespołowego zagospodarowania użytków rolnych. Pojedyncze niewielkie działki nie są z reguły atrakcyjne dla potencjalnych dzierżawców, jednakże wraz z przylegającymi działkami tworzą większy areał, który ma znaczącą wartość gospodarczą poprzez swój potencjał paszowy. Istota proponowanego rozwiązania polega na wykreowaniu „stowarzyszeń właścicieli ziemi oferowanej do wydzierżawienia i wypasu” oraz „zespołów (grup) dzierżawców”. Trzecią stroną współpracy z rolnikami wydzierżawiającymi i dodzierżawiającymi ziemie byłyby oddziały wojewódzkie (i biura powiatowe) Agencji Restrukturyzacji i Modernizacji Rolnictwa, a także Agencja Rynku Rolnego, starostwa powiatowe i urzędy pracy.

\section{Przemiany struktur demograficznych}

Zgodnie z wynikami badań Izasława Frenkla $(2015 ; 2016)$ ludności wiejskiej nadal przybywa, ale przyrost ten jest mniejszy niż ubytek ludności w miastach, zatem w ostatnich trzech latach znów obserwujemy spadek ludności Polski ogółem $^{1}$. W 2008 r., po ponad dziesięcioletnim okresie spadku, liczba ludności Polski zaczęła ponownie rosnąć, jednak tendencja ta była bardzo krótkotrwała,

1 O ile nie zaznaczono inaczej, prezentowane dane dotyczą ludności faktycznie zamieszkałej w danej jednostce podziału terytorialnego. Do kategorii tej zalicza się ludność stale zamieszkałą (zameldowaną na pobyt stały) w danej jednostce oraz ludność przebywającą tam czasowo (zameldowaną na pobyt czasowy) ponad 3 miesiące (zob. Rocznik Demograficzny 2013, GUS, Warszawa 2013, s. 67). Definicja ta obejmuje 
a lata 2012 i 2013 przyniosły ponowny spadek. Utrzymały się natomiast trwające od ponad dekady różnice dynamiki ludności miejskiej i wiejskiej, tj. liczba mieszkańców miast malała, a wsi rosła. Spadek liczby ludności miejskiej uległ jednocześnie znacznemu przyspieszeniu, podczas gdy przyrost ludności wiejskiej utrzymał się w obu okresach na zbliżonym poziomie ${ }^{2}$.

Na przyrost liczby ludności wiejskiej wpływ mają głównie migracje miasto-wieś, w mniejszym zaś stopniu przyrost naturalny, natomiast migracje zagraniczne działają na rzecz zmniejszenia się liczby ludności wiejskiej. Mimo utrzymywania się dodatniego przyrostu naturalnego na wsi wykazuje on silną tendencję zniżkową, co jest związane ze zmniejszaniem się wskaźnika dzietności kobiet. Dzietność na wsi w 2013 r. była o ok. 1/3 niższa od poziomu zapewniającego prostą zastępowalność pokoleń (wynoszącą ok. 2,1 urodzenia na kobietę). Według danych z 2012 r. poziom dzietności na polskiej wsi był niższy niż poziom dzietności ogółem średnio w krajach Unii Europejskiej oraz niższy w porównaniu $\mathrm{z}$ większością krajów tego regionu.

Długość trwania życia na wsi wzrasta. Chociaż ogólny współczynnik zgonów na wsi w latach 2010-2013 utrzymywał się na podobnym poziomie, przeciętny czas trwania życia mężczyzn zwiększył się w tym okresie z 71,4 roku do 72,4 roku, a kobiet - z 80,7 do 81,1 roku. Mężczyźni na wsi żyją krócej niż w miastach i różnica ta w 2013 r. wyniosła 1,1 roku. W odróżnieniu od mężczyzn mieszkanki wsi żyją dłużej niż mieszkanki miast, choć przewaga ta stopniowo maleje z 0,4 roku w 2008 r. do poziomu bliskiego zeru w $2013 \mathrm{r}$. W porównaniu z krajami starej UE-15 w Polsce na wsi w 2012 r. przeciętne trwanie życia było krótsze. Natomiast w porównaniu z nowymi krajami członkowskimi wskaźniki długości życia są, z kilkoma wyjątkami, bardziej korzystne w Polsce.

Saldo migracji wewnętrznych na wsi było dodatnie i zróżnicowane pod względem charakterystyki migrantów oraz kierunku migracji. Saldo migracji na wsi było dodatnie w większości grup wiekowych z wyjątkiem osób w wieku 20-24 i 25-29 lat. W strukturze płci migrantów przeważają kobiety. Najwięcej migrantów ze wsi kieruje się do niewielkich miast (10-50 tys. mieszkańców) i miast największych (100 tys. i więcej mieszkańców), natomiast najwięcej migrantów na wieś migruje z miast największych. W obu kierunkach dominują migracje wewnątrz województw.

\footnotetext{
także wszystkie osoby zameldowane w kraju, ale przebywające za granicą (bez względu na okres ich nieobecności).

2 Przy porównaniu zmian liczby ludności w latach 2008-2010 i 2010-2013 stan w 2010 r. przyjęto w dwóch opracowanych przez GUS wersjach: przed korektą wynikającą z uwzględnienia wyników NSP 2011 i po takiej korekcie. $Z$ danych w pierwszej wersji korzystano przy obliczeniu dynamiki zmian w latach 2008-2010, a w drugiej - przy obliczeniach dla lat 2010-2013. To samo dotyczy omawianych w dalszym ciągu innych wskaźników demograficznych.
} 
Struktura płci ludności wiejskiej prawie nie uległa zmianom, natomiast można zauważyć postępujące starzenie się ludności wiejskiej. W latach 20102013 ogólny współczynnik feminizacji utrzymał się na tym samym poziomie tj. 1006 kobiet na 1000 mężczyzn. Wartość współczynnika feminizacji w wieku 20-29 lat (wiek, w którym kobiety najczęściej zawierają związek małżeński) zmalała z 937 do 935 kobiet na 1000 mężczyzn (w miastach z 989 do 987). Z kolei największe niedobory młodych kobiet występują głównie $\mathrm{w}$ regionach o trwającym do niedawna przez wiele lat ujemnym dla wsi saldzie migracji wieś-miasto, zwłaszcza we wschodniej i częściowo centralnej części kraju. Na tych obszarach też najbardziej zaawansowany jest poziom starzenia się ludności wiejskiej. W 2013 r. najwyższy odsetek ludności w wieku poprodukcyjnym i jedną z najwyższych medianę wieku odnotowano w województwie podlaskim (20,3\% i 39,6 roku), tam też najniższy był współczynnik feminizacji w wieku 20-29 lat (886). W latach 2010-2013 odnotowano wzrost mediany wieku na wsi z 36,2 do 37,3 roku (w miastach z 39,3 do 40,2 roku). Mimo postępującego procesu starzenia się społeczeństwa poziom starości ludności wiejskiej w Polsce należy do najniższych wśród wszystkich krajów Unii Europejskiej.

Analiza podstawowych założeń i wyników najnowszej prognozy ludności Polski opracowanej przez GUS dla okresu 2014-2050 wskazuje na to, że liczba kobiet $w$ wieku rozrodczym w latach 2013-2050 zmniejszy się w skali kraju z ok. 9,3 mln do 5,8 mln (o 37,8\%), co skutkować będzie zmniejszeniem liczby urodzeń. Dodatkowym czynnikiem zmniejszania się liczby urodzeń będzie także wzrost odsetka kobiet o najniższej płodności (35-49 lat). Przewiduje się, że ujemny przyrost naturalny będzie stanowił główny czynnik przewidywanego zmniejszenia się liczby ludności kraju. Skala spadku będzie sukcesywnie narastać: od ok. 300 tys. w pięcioleciu 2015-2019 do ponad 800 tys. w każdym pięcioleciu po 2035 r. Prawie 98\% przewidywanego w całym okresie prognozy spadku obejmie mieszkańców miast, natomiast liczba ludności wiejskiej początkowo będzie się zwiększać (głównie przez dodatnie saldo migracji wewnętrznych), zmniejszając się następnie do ok. 15,1 mln w 2050 r. W rezultacie odsetek ludności wiejskiej zwiększy się w całym okresie prognozy z $39,5 \%$ do $44,5 \%$.

\section{Rozwój wiejskiego rynku pracy}

Badania Izasława Frenkla (Frenkel 2015) pokazują, że na wsi zmniejszał się udział ludności $w$ wieku przedprodukcyjnym, natomiast wzrósł $w$ wieku produkcyjnym i poprodukcyjnym. Wskaźniki zatrudnienia ludności bezrolnej na wsi są niższe w porównaniu z ludnością użytkującą gospodarstwo rolne i ludnością miejską. W pierwszym przypadku wynika to w znacznym stopniu z niepełnej 
porównywalności danych obu grup, w drugim zaś - z trudniejszej sytuacji na rynku pracy bezrolnych mieszkańców wsi niż miast. Jednak z biegiem lat różnice malały: w 2003 r. wskaźnik zatrudnienia ludności bezrolnej na wsi był o ok. 11 punktów procentowych niższy niż mieszkańców miast, a w 2013 r. o ok. 7 punktów.

Poziom wskaźników zatrudnienia jest tym wyższy na wsi, im wyższy poziom wykształcenia. Wśród ogółu ludności wiejskiej z wykształceniem wyższym wskaźnik zatrudnienia wynosił w 2013 r. 77,1\%, średnim - 61,3\% i podstawowym lub niższym - 18,1\%. Wśród osób z wykształceniem średnim wskaźnik zatrudnienia był znacznie wyższy dla mających wykształcenie zawodowe niż ogólnokształcące (odpowiednio 67,0 i 46,4\%). Niższy od osób z wykształceniem średnim zawodowym wskaźnik miały również osoby z wykształceniem zasadniczym zawodowym (61,0\%). Wskaźniki zatrudnienia ludności wiejskiej są w Polsce nadal niższe w porównaniu z większością krajów UE i różnią się regionalnie. Szczególnie niskie wskaźniki zatrudnienia na wsi odnotowuje się wśród kobiet i osób starszych w wieku 55-64 lat, w nieco mniejszym stopniu młodzieży w wieku 15-24 lata.

Kontynuuje się proces dezagraryzacji struktury zatrudnienia. Odsetek pracujących głównie w rolnictwie zmniejszył się w skali kraju z 13,0 w 2010 r. do 12,0 w 2013 r. Zdecydowaną większość zatrudnionych w rolnictwie stanowią osoby pracujące na własny rachunek, wśród mieszkających na wsi ich odsetek wynosił w 2013 r. 90,1\%, w tym w rolnictwie indywidualnym 95,9\%. Wśród mieszkańców wsi zatrudnionych poza rolnictwem odsetek pracujących na własny rachunek jest stosunkowo niski i nie wykazuje większych zmian: w latach 2010-2013 kształtował się na poziomie ok. $12 \%$.

Populacja pracujących $w$ rolnictwie indywidualnym charakteryzuje się znacznie starszą strukturą wieku niż pracujących poza rolnictwem. Odsetek pracujących w starszym wieku produkcyjnym wynosił w 2013 r. odpowiednio 45,3 i 31,8, a w wieku poprodukcyjnym 6,4 i 1,2 (wśród pracujących w miastach udziały osób starszych były niższe niż wśród pracujących w rolnictwie, ale wyższe w porównaniu z pracującymi poza rolnictwem na wsi).

Poziom wykształcenia pracujących zwiększa się szybciej na wsi niż w miastach, jednak najniższy poziom wykształcenia nadal mają mieszkańcy wsi pracujący w rolnictwie indywidualnym. Wykształcenie wyższe lub średnie w $2010 \mathrm{r}$. miało $29,6 \%$, a w 2013 r. 34,3\% (w tym wykształcenie wyższe 3,2 i 4,5\%). Poziom wykształcenia mieszkańców wsi pracujących poza rolnictwem był w obu latach znacznie wyższy niż pracujących w rolnictwie, ale niższy w porównaniu z miastami.

Stopa bezrobocia na wsi fluktuuje w ostatniej dekadzie, co w dużej mierze jest związane $\mathbf{z}$ koniunkturą $\mathbf{w}$ kraju. W pierwszych kilku latach po wejściu Polski do UE liczba bezrobotnych szybko malała, później dominowała tendencja zwyżkowa. Wśród ogółu wiejskich bezrobotnych przeważają osoby z bezrolnych 
gospodarstw domowych. W latach 2003-2013 ich udział zwiększył się z ok. 65\% do blisko $75 \%$ wszystkich bezrobotnych mieszkających na wsi. W strukturze bezrobotnych według przyczyn poszukiwania pracy najliczniejszą kategorię stanowią osoby, które straciły pracę, drugą pod względem liczebności grupę stanowili bezrobotni powracający do pracy po przerwie i trzecią bezrobotni podejmujący pracę po raz pierwszy. Najmniej liczną kategorię stanowili bezrobotni, którzy uprzednio sami zrezygnowali z pracy. Znaczną część bezrobotnych stanowią osoby długotrwale poszukujące pracy, a średni czas poszukiwania pracy wynosił ok. 12 miesięcy. Według średniorocznych danych z 2012 r. stopa bezrobocia ludności wiejskiej w Polsce była zbliżona do średniej unijnej. Dotyczy to jednak tylko stopy bezrobocia ludności ogółem (w wieku 15-64 lat), natomiast wśród młodzieży w wieku 15-24 lat i ogółu kobiet była ona na polskiej wsi wyższa, a w pozostałych grupach wieku i wśród ogółu mężczyzn niższa od średniej unijnej.

Wśród ludności użytkującej gospodarstwo rolne nadal utrzymuje się wysokie bezrobocie ukryte. Skalę tego zjawiska obrazuje m.in. porównanie rocznego czasu pracy osób statystycznie traktowanych jako pracujące w gospodarstwie rolnym z czasem pracy osoby pełnozatrudnionej, tj. pracującej w ciągu roku 2120 godzin lub więcej. Według danych Powszechnego Spisu Rolnego 2010 dotyczących pracujących wyłącznie w gospodarstwie kryterium osoby pełnozatrudnionej spełniało 27,6\%. Pozostali pracowali w niepełnym wymiarze i było ich aż 2062 tys. osób. Wśród nich $51,8 \%$ pracowało co najwyżej na $1 / 2$ czasu pracy osoby pełnozatrudnionej (tzw. AWU), w tym 37,5\% co najwyżej na $1 / 4$ AWU. Wśród mężczyzn odsetek pełnozatrudnionych był wyższy $(33,1)$ niż wśród kobiet $(22,2)$. Odsetki osób pełnozatrudnionych rosną w miarę wzrostu obszaru gospodarstwa, co wskazuje, że chociaż w przypadku części pracujących niepełne zatrudnienie może wiązać się z ograniczeniami starszego wieku, niepełnosprawnością czy nauką, a wśród kobiet z zaangażowaniem $\mathrm{w}$ prace domowe, jego główną przyczyną jest rozdrobnienie gospodarstw rolnych.

Krótkookresowe zarobkowe migracje zagraniczne wykazują korzystny wpływ na lokalny rynek pracy na wsi, w przeciwieństwie do migracji długookresowych. Dla lokalnego rynku pracy emigracja czasowa stanowi czynnik łagodzący nierównowagę podaży i popytu pracy. Dodatkowo wiąże się z poprawą sytuacji bytowej mieszkańców wsi poprzez transfery środków pieniężnych, co pośrednio wspiera rozwój lokalnej gospodarki, zarówno poprzez wydatki konsumpcyjne gospodarstw domowych, jak i potencjalne inwestycje w stworzenie dodatkowych miejsc pracy. Częstokroć sukces nowej działalności gospodarczej może zapewnić nie tylko kapitał początkowy, ale również pomysł i doświadczenie zdobyte za granicą. Problemem społecznym w rozwoju obszarów wiejskich jest natomiast migracja długookresowa i trwała, która negatywnie oddziałuje na strukturę demograficzną 
i jakość kapitału ludzkiego, zwłaszcza w przypadku odpływu ludzi młodych i wykształconych.

Jak zauważa Krzysztof Wasielewski (Wasielewski 2014), wśród przyczyn trudnej sytuacji na rynku pracy, zwłaszcza młodych ludzi, można wskazać niedostosowanie kierunków kształcenia do zmieniających się wymogów potencjalnych pracodawców. Jest to wynikiem braku rozwiązań systemowych w zakresie doradztwa zawodowego w szkołach i w przepływie informacji o zapotrzebowaniu na pracę pomiędzy pracodawcami a instytucjami edukacyjnymi. Problem ten odnosi się również do osób starszych, które przez przekwalifikowanie zwiększyłyby szansę na ponowne zatrudnienie. Jednakże kształcenie dorosłych jako element systemu zapobiegania bezrobociu jest na terenach wiejskich wciąż słabo rozpowszechnione.

W Polsce dochody $z$ rolnictwa na pełnozatrudnionego wzrosły między 2005 a 2013 r. w ujęciu realnym z 2432 euro do 4113 euro, nadal jednak stanowily tylko 1/3 średniej wartości unijnych dochodów rolniczych (Zawalińska, Majewski, Wąs 2015). Szybka dynamika zmian dochodów była możliwa dzięki przemianom strukturalnym w sektorze rolnym i poprawie produktywności czynników produkcji, szczególnie pracy. Przyrost dochodów rolniczych w Polsce od wstąpienia do UE bezpośrednio wynikał ze wzrostu wartości produkcji rolniczej oraz sukcesywnego wzrostu płatności bezpośrednich. Najwyższą wartość produkcji z hektara osiągały gospodarstwa duże, ale najsilniej w analizowanym okresie wzrosły dochody w gospodarstwach małych. Dochody z rolnictwa w UE w ujęciu długookresowym charakteryzują się dynamiką wzrostową, przy czym w poszczególnych krajach i poszczególnych okresach (np. w czasie kryzysów) wahania dochodów bywają znaczne i odbiegają od długookresowego trendu.

Obserwowany wzrost dochodów z rolnictwa w UE jest możliwy dzięki systematycznemu spadkowi liczby pracujących $w$ rolnictwie. Wraz z rozwojem gospodarczym dochody rolnicze rosną w ujęciu absolutnym, ale maleją $\mathrm{w}$ strukturze PKB. Duży udział w tych dochodach mają dotacje w ramach WPR. Wyraźnie widać, że zmienność dochodów z rolnictwa była wyższa w krajach rozszerzonej UE ogółem niż w krajach UE-15. Częściowo był to skutek silnych, nowych bodźców działających na wzrost dochodów w nowych krajach członkowskich. Jednak nadal występowały duże różnice między starymi i nowymi państwami UE w wartościach dochodów $\mathrm{z}$ rolnictwa w przeliczeniu na AWU, z wyraźną przewagą tych pierwszych.

\section{Rozwój przestrzenny obszarów wiejskich}

Według wyników badań Moniki Stanny (Stanny 2014a) lokalne uwarunkowania rozwoju obszarów wiejskich w Polsce ujawniają porządek w relacji centrumperyferia. Rozpoznana polaryzacja przestrzenna (koncentracja i dekoncentracja 
czynników) w rozkładzie jednorodnych typów gmin pod względem podobieństwa zachodzących w nich kombinacji ocen zasobów lokalnych ma cechy relacji hierarchicznej. Proces rozwoju jest wypadkową dwóch przeciwstawnych tendencji: do koncentracji i do rozpraszania, których efekty są warunkowane kumulującym się wpływem: korzyści skali, kosztów transportu oraz wielkości popytu. Wpływ czynników historycznych okazuje się niejednoznaczny, ale istotne są historyczne uwarunkowania, takie jak dotychczasowa ścieżka rozwojowa (path-dependency) czy tożsamość i dziedzictwo kulturowe.

Analiza lokalnych warunków społecznych i warunków gospodarowania przeprowadzona przez Andrzeja Rosnera i Monikę Stanny wykazała, że na obszarach wiejskich występują dwa typy gmin peryferyjnych i trzy typy gmin centralnych (Rosner, Stanny 2014; Czarnecki, Kłodziński, Stanny 2015; Stanny, Strzelczyk 2015). Jeśli chodzi o gminy peryferyjne, to występują dwa typy gmin, tj. 1) typ, w którym występuje peryferyjność z rezerwą zasobów pracy, oraz 2) typ, w którym występuje peryferyjność $\mathrm{z}$ zaawansowaną depopulacją. W przypadku gmin centralnych korzystających $\mathrm{z}$ renty położenia, zamożnych (o wysokiej zdolności do kreowania dochodów) występują: 3) typ, w którym zasobność jest funkcją renty miejskiej, o największej koncentracji kapitałów; 4) typ, w którym zasobność jest funkcją sąsiedztwa, $\mathrm{z}$ cechami wysokiej koncentracji zasobów pracy i korzystnych warunków bytowych, oraz 5) typ, w którym zasobność jest funkcją sąsiedztwa, $\mathrm{z}$ akumulacją zasobów wiedzy.

Istotny wpływ na strukturę zasobów lokalnych obszarów wiejskich ma geograficzna renta położenia, będąca „niemobilnym” czynnikiem rozwoju. Warunki społeczne i warunki gospodarowania mają jednak w znacznym stopniu charakter czynników „mobilnych”. To znaczy z jednych obszarów są wymywane, po to, by gdzie indziej się gromadzić, prowadząc do różnic w poziomie ich akumulacji. Stąd też niejednoznacznie determinują efekt rozwoju społeczno-gospodarczego w każdym wyróżnionym typie. Jednoznaczność jest wyraźna w przypadku typów o skrajnie różnej charakterystyce struktur zasobów lokalnych (typów biegunowych). Potwierdzono, że zgodnie z założeniami nowej teorii wzrostu endogenicznego nierówność rozwoju w przestrzeni to konsekwencja różnic w poziomie akumulacji szeroko pojętego kapitału (materialnego i ludzkiego).

Jakość i wielkość endogenicznych zasobów na obszarach wiejskich jest silnie zróżnicowana przestrzennie, co powoduje, że nie ma jednego modelu wsparcia rozwoju tych obszarów (Nurzyńska 2014a, b). Regiony, w których są zlokalizowane obszary wiejskie charakteryzujące się kumulacją negatywnych zjawisk społeczno-gospodarczych, muszą umiejętnie i precyzyjnie formułować własną regionalną politykę inwestycyjną na podstawie unowocześnienia endogenicznych zasobów obszarów wiejskich lub budowy nowych innowacyjnych podstaw wzrostu. 
Potrzebne są specyficzne dla każdego obszaru modele rozwoju, które „uruchomią” te zasoby celem zbudowania „masy krytycznej” i zainicjowania realnych impulsów rozwojowych.

Gminy rozwijają się nie tylko w różnym tempie, ale również według różnych scenariuszy, które można pogrupować w cztery profile strategii rozwojowych gmin. Profil pierwszy to w miarę zrównoważony rozwój pod względem proporcji składowych, z pewną przewagą na rzecz równowagi rynku pracy. Również względnie zrównoważony charakter ma profil drugi, z tym jednak, że na rzecz awansu gminy oddziałuje rozwój lokalnego rolnictwa, a na rzecz spowalniania rozwoju powolne zmiany w sektorze pozarolniczym. Trzeci profil rozwoju charakteryzuje się regresem znaczenia funkcji rolniczej przy jednoczesnym ponadprzeciętnym wzroście znaczenia gospodarczego sektorów pozarolniczych. Rozwój ten dokonuje się jednak w warunkach niezrównoważonego rynku pracy i przy niekorzystnych zmianach struktur demograficznych. Wreszcie czwarty profil ma charakter silnie niezrównoważony, motorem rozwoju stają się równowaga rynku pracy oraz dobre warunki mieszkaniowe. Jednocześnie na rzecz regresu społeczno-gospodarczego oddziałuje problematyka związana $\mathrm{z}$ finansami publicznymi i kwestiami związanymi z edukacją. Powyższe typy strategii rozwojowych gmin występują z różną częstotliwością w różnych regionach kraju - zdecydowana większość gmin rozwijających się według typu 1 i 2 znajduje się w zachodniej części kraju, z kolei typ 3, a zwłaszcza 4 są charakterystyczne dla wschodniej części kraju.

Jak wykazały badania Katarzyny Zawalińskiej (Zawalińska 2015), odporność obszarów wiejskich na kryzysy ekonomiczne w dużej mierze zależy od ich lokalizacji, pełnionych funkcji oraz stopnia specjalizacji. Po pierwsze, obszary wiejskie blisko miast i centralnej części kraju mają większe szanse na uniknięcie kryzysu lub szybsze wyjście z niego - co wiąże się z większymi możliwościami na rynkach zbytu i rynku pracy. Po drugie, obszary wiejskie zaangażowane w produkcję energii odnawialnej mniej tracą (lub więcej korzystają) na kryzysie, gdyż wtedy ceny energii są zwykle szczególnie wysokie. Po trzecie, mniej narażone na kryzys są wielofunkcyjne obszary wiejskie (w przeciwieństwie do monofukcyjnych), z racji tego, że ryzyko utraty dochodów jest zmniejszone poprzez ich dywersyfikację. Dodatkowym aspektem pomagającym w uodparnianiu się obszarów wiejskich na kryzysy jest inwestowanie w kapitał ludzki bardziej niż w infrastrukturę, gdyż w momencie kryzysu koszty utrzymania infrastruktury mogą go pogłębiać, podczas gdy wykształceni ludzi mogą się przekwalifikowywać i dostosowywać do zmieniającej się koniunktury, jednocześnie niwelując skutki kryzysu.

Badania Marka Kłodzińskiego dotyczące rozwoju przedsiębiorczości w ujęciu przestrzennym pokazują, że Polska wieś jest bardzo zróżnicowana (Kłodziński 2014a, b; Kłodziński 2015a, b). Przedsiębiorczość na marginalnych terenach 
wiejskich jest odmienna od przedsiębiorczości na terenach okalających duże aglomeracje miejskie zarówno pod względem liczby firm, jak i poziomu ich rozwoju, wykształcenia właścicieli, dostępności rynków zbytu itd. Na terenach wiejskich funkcjonuje $25 \%$ ogólnej liczby krajowych podmiotów gospodarczych. Pod względem rozwoju przedsiębiorczości korzystnie wyglądają jedynie gminy położone w bezpośrednim sąsiedztwie dużych aglomeracji miejskich.

Wśród wielu barier rozwojowych przedsiębiorczości wiejskiej najważniejsze wydaje się niedostateczne infrastrukturalne otoczenie biznesu, brak dobrego doradztwa uwzględniającego specyfikę pracy przedsiębiorcy wiejskiego. Firmy wiejskie, działające głównie na rynku lokalnym, kierują się przede wszystkim krótkookresowymi celami i w wielu wypadkach są nastawione na przetrwanie, a nie rozwój. Przedsiębiorczość wiejska jest uprawiana na małą skalę i w dużym rozproszeniu, przy jednocześnie małej różnorodności branżowej, co często powoduje, że wiele wysiłku jest poświęcone przez firmy na walkę konkurencyjną ze sobą. Ponadto na wsi istnieją ogromne trudności ze znalezieniem dobrze wykwalifikowanej kadry pracowniczej. Sektor małej i średniej przedsiębiorczości na wsi wobec wyżej wspomnianych barier nie jest w stanie zrekompensować znaczącego ubytku miejsc pracy w rolnictwie. Poświęcenie większej uwagi niż dotychczas dominującej formie przedsiębiorczości na wsi - mikrofirmom - jest niezbędnym elementem każdej strategii dywersyfikacji gospodarki wiejskiej.

\section{Przeobrażenia społeczne polskiej wsi}

Badania Krystyny Szafraniec pokazują, że przeobrażenia polskiej wsi zachodzą sukcesywnie, a zasadnicze etapy tego procesu bardziej wyznaczają „fazowe przejścia" od jednych wzorów kulturowych do drugich aniżeli polityczne decyzje czy wydarzenia (Szafraniec 2014; Szafraniec 2015). Niemniej akcesja Polski do UE (również ze względu na fundusze unijne i aplikacje Wspólnej Polityki Rolnej) stanowi dziś zasadniczy kontekst analiz w tym obszarze, dostarczając nie tylko wyrazistej cezury czasowej, lecz również nowych punktów widzenia na społeczną rolę wsi, rolnictwa, chłopów.

Zmniejsza się cywilizacyjny dystans wsi wobec miasta, co znajduje wyraz w śmielszych planach edukacyjnych wiejskiej (zwłaszcza chłopskiej) młodzieży, i w nieco większej (choć niewspółmiernej do skali finansowego wsparcia i bardzo selektywnej) lojalności rolników wobec systemu. Zmniejsza to polityczny dystans tej grupy w stosunku do reszty społeczeństwa i czyni bardziej płynnym proces społecznej zmiany. Preferencje ustrojowe mieszkańców wsi różnią się nadal od tych odnotowywanych w odniesieniu do mieszkańców ośrodków miejskich, gdzie uwidacznia się nieco większe poparcie dla rozwiązań rynkowych (nad socjalnymi), 
demokratycznych (nad autorytarnymi), dla inkluzywnego typu wspólnoty czy (nawet) typu obywatelstwa, niemniej różnice nie są już tak wyraźne jak odnotowywane na początku polskich przemian. Również różnice pokoleniowe na wsi w odniesieniu do tych kwestii nie są tak duże jak w początkowym okresie przemian, choć nadal większe aniżeli obserwowane między starszym i młodym pokoleniem w mieście.

Jak wykazała Sylwia Michalska (Michalska 2015a, b, c), wśród przyczyn niskiej aktywności społecznej kobiet wiejskich wymienić można zarówno standardowe bariery, które dotyczą wszystkich obywateli, jak i bariery specyficzne. Wśród standardowych przyczyn niskiej aktywności społecznej można wymienić uwarunkowania historyczne (kultura folwarczna, pozaborowa mentalność antypaństwowa, pozostałości po systemie komunistycznym), bariery instytucjonalne (stan państwa, słabość instytucji, zła jakość rządzenia) i makrostrukturalne (brak rozwiniętej klasy średniej, zmienne socjo-demograficzne, ubóstwo) oraz czynniki osobowościowe. Część z tych barier jest dla mieszkanek wsi trudniejsza do pokonania niż dla innych obywateli. Kobiety wiejskie napotykają ponadto bariery specyficzne, takie jak normy kulturowe, które każą kobietom wypełniać znaczną część obowiązków domowych, oraz brak instytucji wspierających kobiety w aktywnościach opiekuńczych (żłobków, przedszkoli, świetlic, dziennych domów opieki, przychodni), przekładający się w bezpośredni sposób na ich obciążenie i niemożność angażowania się w innych niż opiekuńcze sferach aktywności. Aktywność społeczna i polityczna kobiet wiejskich jest ograniczona także barierami obyczajowo-środowiskowymi (m.in. wysokim poziomem kontroli społecznej), stereotypami i izolacją przestrzenną.

Wyniki badań Marii Halamskiej (Halamska 2014a, b; Halamska 2015a, b; Halamska 2016) ukazują postępujący proces gentryfikacji społecznej polskiej wsi, który charakteryzuje się zmiennym rytmem w czasie i zróżnicowaniem przestrzennym. Nasilenie zmian związanych z tym procesem przypada na lata 90 . i początek lat 2000. Można zaobserwować zróżnicowanie udziału klasy średniej w podziale na typy wsi, wyróżnione ze względu na strukturę gospodarki i poziom urbanizacji: im słabsza gospodarka, tym mniejszy udział przedstawicieli klasy średniej. Klasa ta jest w różny sposób z wsią związana, lecz już sama jej liczna obecność (jak np. we wsiach podmiejskich) narzuca pewien typowy dla niej, konsumpcyjny styl życia jako wzór.

Analiza struktury społeczno-demograficznej grupy zawodowej rolników pozwoliła wyróżnić trzy grupy zawodowe: (a) wyspecjalizowanych rolników rynkowych, (b) wielofunkcyjnych rolników rynkowych oraz (c) quasi-chłopów, czyli grupę zapewniającą sobie i swoim gospodarstwom domowym żywność, miejsce zamieszkania i dochody. Podstawą tego grupowania są takie istotne cechy definicyjne grup, jak samodzielność oraz cel produkcji. Wyróżnione w ten sposób zbiorowości rolników różnią się także cechami społeczno-demograficznymi: wiekiem, 
poziomem wykształcenia, dochodami. Grupą najmłodszą i najlepiej wykształconą są rynkowi rolnicy wyspecjalizowani, najstarszą zaś, najgorzej wykształconą oraz słabiej zdominowaną przez mężczyzn są quasi-chłopi.

\section{Rozwój instytucjonalny i organizacyjny na wsi}

Zgodnie z wynikami badań Ryszarda Kamińskiego (Kamiński 2014) najprężniej działające dziś organizacje na wsi to tradycyjne Koła Gospodyń Wiejskich oraz Ochotnicze Straże Pożarne, ale wyraźnie wchodzą już też nowe formy zaangażowania społecznego. Do tej grupy należą stowarzyszenia prowadzące niepubliczne szkoły i przedszkola oraz różnego rodzaju inicjatywy rozwoju wsi, organizacje powstałe na bazie wiosek tematycznych itp. W początkowym okresie udziału Polski w strukturach Unii Europejskiej najważniejszym zadaniem dla wielu instytucji, $w$ tym organizacji pozarządowych, było pozyskiwanie jak największych środków „unijnych”. Nadal dla wielu organizacji misją i istotą jest pozyskiwanie środków z zewnątrz.

Specyficzną cechą polskich organizacji pozarządowych jest to, że mają bardzo częste kontakty $z$ sektorem publicznym i bardzo rzadkie między sobą. Sytuacja ta jest niejako wynikiem nasilającej się konkurencji o dostęp do środków finansowych. Dużym problemem jest upolitycznienie życia lokalnego oraz uzależnienie organizacji pozarządowych od władz lokalnych (finansowe bądź związane z korzystaniem z pomieszczeń, urządzeń itp. stanowiących własność gmin, powiatów lub podległych im jednostek). Poza nielicznymi wyjątkami, brak lokalnych czy regionalnych sieci trzeciego sektora.

Praca Ruty Śpiewak, Dominiki Milczarek-Andrzejewskiej i Anny Ciechomskiej (Śpiewak, Milczarek-Andrzejewska, Ciechomska 2016) dotycząca formalnych organizacji rolniczych i ich działalności wskazuje, że trudno jest jednoznacznie oszacować całkowitą liczbę członków organizacji rolniczych w Polsce, gdyż często brakuje danych lub nie są one w pełni wiarygodne. W badaniach IRWiR analizowano organizacje zrzeszające członków prowadzących produkcję rolniczą niezależnie od formy prawnej (czyli zrzeszające nie tylko rolników indywidualnych, ale także grupy producentów rolnych, rolnicze spółdzielnie produkcyjne, przedsiębiorstwa prowadzące produkcję rolną). Główne typy organizacji, jakie wyróżniono, to: 1) izby rolnicze; 2) związki zawodowe i organizacje pracodawców; 3) organizacje branżowe. Najważniejsze różnice między poszczególnymi typami organizacji rolniczych dotyczą: umocowania prawnego, sposobu ich finansowania, celów działania, struktur organizacyjnych i zasięgu terytorialnego.

Aktywność części polskich organizacji rolniczych przejawia się w ich przynależności do organizacji międzynarodowych i udziale $w$ różnego rodzaju 
ciałach opiniotwórczych (Milczarek-Andrzejewska, Śpiewak 2015). W Komitecie Rolniczych Organizacji Zawodowych (COPA) znajduje się sześć polskich organizacji rolniczych. Natomiast Związek Zawodowy Centrum Narodowe Młodych Rolników (CNMR) od 1999 r., jako pierwszy w naszej części Europy, stał się członkiem CEJA - Europejskiej Rady Młodych Rolników. Polskie organizacje rolnicze komunikują się z otoczeniem głównie poprzez wydawanie specjalistycznych czasopism czy stronę internetową. Dużo mniej korzysta z portali społecznościowych.

Badania Ruty Śpiewak (Jasiński, Michalska, Śpiewak 2014; Śpiewak 2014) dotyczące kooperatyw spożywczych i zakupowych pokazują, że dzięki ich rozwojowi alternatywne sieci żywności w ostatnich latach bardzo zyskały na popularności. Przyczyniają się one do skracania dystansu między producentami i konsumentami, eliminując wszystkich pośredników. W przypadku sieci bazujących na targowisku pojawia się dodatkowo element fizycznego skracania dystansu. Zwykle gospodarstwa współpracujące z sieciami są niewielkie (do ok. 20 ha), mają charakter gospodarstw rodzinnych oraz w gospodarstwach tych ogranicza się zużycie nawozów sztucznych i dba się o dobrostan zwierząt. Nierzadko rolnicy dostarczający produkcję zarówno na targowiska, jak i do kooperatywy prowadzą działalność przetwórczą (zwykle nieformalną), co przyczynia się do możliwości zwiększenia ich dochodów.

Dla wielu rolników współpraca $\mathrm{z}$ kooperatywami ma wymiar nie tylko finansowy, ale też ideologiczny. Chodzi o ograniczanie wpływu i znaczenia dużych hurtowni i kompanii spożywczych oraz możliwość propagowania wyższej jakości żywności wśród mieszkańców miast. Alternatywne sieci bazują przede wszystkim na zaufaniu konsumentów do dostawców, przez co przyczyniają się również do budowy silniejszych relacji między wsią a miastem. Są one narzędziem prorozwojowym, służącym promocji bardziej zrównoważonej gospodarki, spełniając trzy wskazane przez Terry'ego Marsdena i Robertę Sonnino (Marsden, Sonnino 2008) warunki: 1) stanowią wartość dodaną, zarówno w postaci wzrostu dochodów, jak i możliwości zatrudnienia w sektorze rolnym; 2) służą konstruowaniu nowego sektora rolnego, który spełnia oczekiwania społeczeństwa; 3) służą redefinicji i rekonfiguracji wiejskich zasobów, zarówno w obrębie samego gospodarstwa, jak i poza nim.

\section{Wpływ polityk dla wsi i rolnictwa na rozwój obszarów wiejskich}

Wnioski z badań Iwony Nurzyńskiej (Nurzyńska 2014a; Drygas, Nurzyńska 2015) wskazują, że problemów rozwojowych obszarów wiejskich nie rozwiąże sama WPR, potrzebne są zintegrowane działania pozostałych polityk unijnych. Nowe instrumenty UE, w tym Zintegrowane Inwestycje Terytorialne (ZIT) i Rozwój 
Lokalny Kierowany przez Społeczność (RLKS), niosą ze sobą liczne potencjalne korzyści, promując zintegrowane wykorzystanie funduszy UE, a co za tym idzie odchodzenie od sektorowego podejścia do polityk publicznych.

Konsolidacja i koordynacja wielu funduszy i wielu programów, zasilanych $\mathrm{z}$ budżetu unijnego i krajowego, stwarza wiele trudności. Widać to było m.in. w poprzednim okresie programowania i finansowania rozwoju (2007-2013), w tym w realizacji PROW. W nowym okresie programowania (2014-2020) podjęto próbę konsolidacji i koordynacji działań prorozwojowych w ramach tzw. Umowy Partnerstwa. Odwołuje się ona do głównych celów i ram polityk wspólnotowych zaprezentowanych w unijnym dokumencie „Europa 2020”. Zarówno dokument strategiczny „Europa 2020”, jak i polskie dokumenty strategiczne dotyczące okresu 2014-2020 wyrażają nowe podejście do programowania i wspierania rozwoju. Przemiany instytucjonalne, jakich ono wymaga, przebiegają wolno i dają efekty niekiedy dość odroczone - opóźnienia już są widoczne (Milczarek-Andrzejewska, Zawalińska 2015)

Katarzyna Bańkowska zwraca uwagę, że reformy polityki Unii Europejskiej, propagując „zazielenienie” postaw Europejczyków, wykorzystują w tym celu liczne obwarowania prawne powiązane $z$ udzieleniem wsparcia finansowego (Bańkowska, Król 2014; Bańkowska 2015; Bańkowska, Klimkowski, Gruda 2015; Bańkowska 2016). W długim okresie takie podejście może uzależnić dbałość o przyrodę od rozwiązań prawnych i zachęt finansowych. Trwalsze efekty dałoby raczej wykształcenie w społeczeństwie wewnętrznego przekonania o konieczności podejmowania wskazanych działań niezależnie od rygorów finansowo-prawnych. $\mathrm{Z}$ drugiej strony dotychczasowe mechanizmy renty politycznej przyczyniły się do wyodrębnienia się następujących funkcji środowiskowych obszarów wiejskich: 1) zachowanie różnorodności biologicznej, 2) dostarczanie alternatywnych źródeł energii, 3) propagowanie ekologicznych metod produkcji żywności, 4) utrzymywanie użytków proekologicznych i 5) kontynuacja gospodarki na terenach o niekorzystnych warunkach gospodarowania.

W najbliższych latach można spodziewać się wzrostu znaczenia „niebieskich funkcji” obszarów wiejskich - związanych $\mathrm{z}$ wytwarzaniem energii - którym winno towarzyszyć dostosowanie prawno-administracyjne, ułatwiające realizację narzuconych ambitnych celów klimatycznych. Zaostrzenie ram polityki klimatyczno-energetycznej UE będzie skutkowało ciągiem przeobrażeń na wsi. Rolnictwo będzie musiało zmierzyć się z podwójnym wyzwaniem - redukcją emisji i jednoczesną adaptacją do zmieniających się warunków gospodarowania, zmianie ulegną również proporcje pełnionych przez wieś funkcji. Postępujący proces przemian będzie wymagać nie tylko dostosowań oddolnych, lecz również działań i wsparcia ze strony administracji państwowej. 
Badania Mirosława Drygasa (Drygas 2014a) pokazują, że mimo kryzysu ekonomicznego przypadającego na czas reformy dwóch dużych polityk rolnych - Wspólnej Polityki Rolnej w UE i Farm Bill w USA - budżety tych polityk zredukowano w mniejszym stopniu niż zapowiadano. Reforma WPR na lata 2014-2020 jest ukierunkowana na: poprawę środowiska przyrodniczego, wzmocnienie sektora małych i średnich gospodarstw rolnych, poprawę innowacyjności oraz zwiększenie produkcji rolnej. Aspekty prośrodowiskowe polityki wzmocniono, wprowadzając do systemu płatności bezpośrednich tzw. zazielenienie (greening) przy jednoczesnym podtrzymaniu wymogów zasady wzajemnej zgodności (cross-compliance). Na ten nowy element kraje członkowskie muszą przeznaczyć nie mniej niż $30 \%$ budżetu swoich płatności bezpośrednich. Wzmocniono też sektor małych i średnich gospodarstw poprzez silniejsze ukierunkowanie i wprowadzenie szerszego wachlarza instrumentarium adresowanego do tych gospodarstw. Będą one wspierane poprzez płatności dodatkowe/redystrybucyjne, na które przeznaczone będzie do 30\% łącznego budżetu płatności bezpośrednich oraz poprzez specjalne wsparcie dla definitywnie wychodzących z rolnictwa w wysokości $10 \%$ budżetu. W II filarze zaś są to środki na restrukturyzację małych gospodarstw oraz rozwój przedsiębiorczości. WPR została również silniej niż uprzednio zorientowana na innowacyjność. $Z$ kolei elementem zmian proprodukcyjnych w WPR jest zniesienie kwot mlecznych od $2015 \mathrm{r}$. oraz kwot cukrowych od $2018 \mathrm{r}$.

Reforma polityki rolnej w USA 2014-2023 w największym stopniu cięciami objęła programy wspierające dochody rolników, płatności antycykliczne oraz płatności z tytułu produkcji rolniczej. Programy wspierające dochody z produkcji rolniczej (commodity programs) obejmują: kukurydzę, pszenicę, soję, bawełnę, ryż, orzeszki ziemne. Dla tych upraw zniesiono dotychczasowy system płatności bezpośrednich oparty na płatnościach historycznych bez względu na kształtowanie się sytuacji cenowej na rynkach rolnych. Zreformowano również dwa kolejne programy wsparcia: tzw. płatności antycykliczne (Counter-Cyclical Payments) oraz program płatności z tytułu produkcji roślinnej (Average Crop Revenue Election). Zmiany te mają przynieść oszczędności około 14,3 mld USD. Wzbudzający największe kontrowersje w trakcie negocjacji program bonów żywnościowych ostatecznie został zmniejszony w niewielkim stopniu, o około 8 mld USD. Trzecią grupą programów, na którą zaplanowano zmniejszenie wydatków o około 3,9 mld USD, są programy ochrony zasobów naturalnych (conservation programmes). Jednocześnie przywrócono podstawowe wymogi, jakie muszą spełniać farmerzy, aby mogli ubiegać się o wsparcie w ramach systemu ubezpieczeń roślin uprawnych.

Reforma rolna w USA skutkowała znaczącym zwiększeniem nakładów finansowych na wsparcie ubezpieczeń upraw oraz na sektor badań i rozwoju ( $r e$ search and development - R\&D). Wydatki na ubezpieczenia upraw wzrosły o około 
5,7 mld USD. W ustawie doceniono także rolę sektora R\&D, zwiększając planowane nakłady o 1,1 mld USD. Na uwagę zasługuje planowane zmniejszanie nakładów na wspieranie wykorzystywania odnawialnych źródeł energii, począwszy od $2017 \mathrm{r}$. W nowym Farm Bill znalazły się też instrumenty umożliwiające rozpoczynającym działalność rolniczą farmerom udział w szkoleniach i dostęp do kapitału.

Porównując budżet WPR 2014-2020 z budżetem amerykańskiej polityki w ramach Farm Bill 2014-2023, zauważamy, że obie polityki znacząco różnią się swoimi priorytetami. W UE obserwujemy poszerzenie obszaru wsparcia z tytułu dostarczania dóbr publicznych przy jednoczesnym znacznym wzroście bezpośredniego wspierania konkretnych kierunków produkcji rolniczej. Z kolei w USA większość budżetu nadal będzie przeznaczana na wsparcie żywnościowe dla konsumentów (m.in. w ramach food stamps).

Na sytuację rolnictwa w UE i USA wpłynie także zawarcie Transatlantyckiego Partnerstwa w dziedzinie Handlu i Inwestycji (TTIP) (Drygas 2015). Zgodnie z szacunkami wdrożenie umowy w życie ma spowodować wzrost PKB w UE o 60 120 mld euro, a w USA o 49,5-94,9 mld euro w zależności od uzgodnionej skali liberalizacji handlu i inwestycji (Francois i in. 2013). Jednak handel produktami rolno-spożywczymi odgrywa niewielką rolę w ogólnych obrotach pomiędzy USA i UE. TTIP może mieć negatywne skutki dla polskiego rolnictwa. Po pierwsze, niższe standardy sanitarne i fitosanitarne oraz niska energochłonność produkcji rolnej w USA, skutkujące niższymi kosztami produkcji w powiązaniu z efektem skali, mogą stanowić o silnym wzroście konkurencyjności eksportu z USA do UE. Po drugie, istnieje groźba napływu zafałszowanej żywności i oszustw związanych $\mathrm{z}$ etykietowaniem oferowanych produktów. Po trzecie, mogą pojawić się kwestie związane z bezpieczeństwem żywności, jak np.: stosowaniem w USA zabronionych w UE stymulatorów wzrostu / hormonów i antybiotyków w chowie zwierząt czy powszechną uprawą organizmów genetycznie modyfikowanych (GMO). Po czwarte, kontrowersje wzbudza zaproponowane przez USA podejście do rozstrzygania sporów między inwestorami a poszczególnymi krajami, które to spory miałyby rozstrzygać prywatne instytucje arbitrażowe w USA. To wszystko stanowi potencjalne zagrożenie eliminacji z rynków lokalnych dużej grupy polskich gospodarstw rolnych. Zapobieganie potencjalnie negatywnym skutkom TTIP w Polsce może polegać $m$.in. na sieciowaniu rolników prowadzących małe i średnie gospodarstwa w systemie sprzedaży bezpośredniej na rynkach lokalnych.

\section{Podsumowanie}

$\mathrm{W}$ artykule przedstawiono wybrane wnioski $\mathrm{z}$ badań statutowych prowadzonych w IRWiR PAN w latach 2014-2015 dotyczących: struktury obszarowej sektora 
gospodarstw indywidualnych, przemiany struktur demograficznych, wiejskiego rynku pracy, rozwoju instytucjonalnego i organizacyjnego na wsi, rozwoju przestrzennego obszarów wiejskich oraz polityki rozwoju obszarów wiejskich i wspólnej polityki rolnej oraz porównania jej z Farm Bill w USA.

Zgodnie z wynikami badań dotyczącymi zmian struktury agrarnej, w efekcie likwidacji PGR i utworzenia Zasobu Własności Rolnej Skarbu Państwa nie nastąpiła poprawa struktury obszarowej sektora gospodarstw indywidualnych, lecz powstanie nowej dużej grupy wielkoobszarowych gospodarstw osób fizycznych oraz prywatnych osób prawnych i polaryzacja w strukturze gospodarstw indywidualnych.

Badania dotyczące przemiany struktur demograficznych pokazują, że ludności wiejskiej nadal przybywa, choć przyrost ten jest mniejszy niż ubytek ludności w miastach. Na przyrost liczby ludności wiejskiej mają wpływ głównie migracje miasto-wieś, w mniejszym zaś stopniu przyrost naturalny, natomiast migracje zagraniczne działają na rzecz zmniejszenia się liczby ludności wiejskiej. Wnioski $\mathrm{z}$ badań na temat wiejskiego rynku pracy pokazują, że zmniejsza się na wsi udział ludności w wieku przedprodukcyjnym i w dalszym ciągu następuje proces dezagraryzacji struktury zatrudnienia. Stopa bezrobocia na wsi fluktuuje w ostatniej dekadzie, co w dużej mierze jest związane z koniunkturą w kraju. Jednak wśród ludności użytkującej gospodarstwo rolne nadal utrzymuje się wysokie bezrobocie ukryte. Problemem jest niski poziom wykształcenia mieszkańców wsi pracujących $\mathrm{w}$ rolnictwie indywidualnym. Ponadto wśród przyczyn trudnej sytuacji na rynku pracy można wskazać niedostosowanie kierunków kształcenia do zmieniających się wymogów potencjalnych pracodawców.

Prace dotyczące rozwoju przestrzennego obszarów wiejskich w Polsce pokazują, że proces rozwoju jest wypadkową dwóch przeciwstawnych tendencji: do koncentracji i do rozpraszania. Ich efekty są warunkowane kumulującym się wpływem: korzyści skali, kosztów transportu oraz wielkości popytu. Jakość i wielkość endogenicznych zasobów na obszarach wiejskich jest silnie zróżnicowana przestrzennie, co powoduje, że nie ma jednego modelu wsparcia rozwoju tych obszarów. Odporność obszarów wiejskich na kryzysy ekonomiczne w dużej mierze zależy od ich lokalizacji, pełnionych funkcji oraz stopnia specjalizacji. Przedsiębiorczość na marginalnych terenach wiejskich jest odmienna od przedsiębiorczości na terenach okalających duże aglomeracje miejskie. Wśród wielu barier rozwojowych przedsiębiorczości wiejskiej najważniejsze wydaje się niedostateczne infrastrukturalne otoczenie biznesu, brak dobrego doradztwa uwzględniającego specyfikę pracy przedsiębiorcy wiejskiego.

Przeobrażenia społeczne polskiej wsi zachodzą sukcesywnie. Zmniejsza się cywilizacyjny dystans wsi wobec miasta, co znajduje wyraz w śmielszych planach edukacyjnych młodzieży wiejskiej i w nieco większej (choć niewspółmiernej do 
skali finansowego wsparcia i bardzo selektywnej) lojalności rolników wobec systemu. Analiza struktury społeczno-demograficznej grupy zawodowej rolników pozwala wyróżnić trzy grupy zawodowe: (a) wyspecjalizowanych rolników rynkowych, (b) wielofunkcyjnych rolników rynkowych oraz (c) quasi-chłopów, czyli grupę zapewniająca sobie i swoim gospodarstwom domowym żywność, miejsce zamieszkania i dochody.

Badania dotyczące rozwoju instytucjonalnego i organizacyjnego na wsi wskazują, że najprężniej działające dziś organizacje na wsi to tradycyjne Koła Gospodyń Wiejskich oraz Ochotnicze Straże Pożarne, choć pojawiają się też nowe formy zaangażowania społecznego. Niestety efektem rywalizacji o dostęp do środków finansowych przez organizacje pozarządowe jest to, że mają bardzo częste kontakty z sektorem publicznym i bardzo rzadkie między sobą. Natomiast trudno jest jednoznacznie oszacować całkowitą liczbę członków organizacji rolniczych w Polsce. Najważniejsze różnice między poszczególnymi typami organizacji rolniczych (izbami rolniczymi, związkami zawodowymi, organizacjami pracodawców i organizacjami branżowymi) dotyczą: umocowania prawnego, sposobu ich finansowania, celów działania, struktur organizacyjnych i zasięgu terytorialnego. $Z$ kolei dzięki rozwojowi kooperatyw spożywczych i zakupowych w ostatnich latach zyskały na popularności alternatywne sieci żywności. Przyczyniają się one do skracania dystansu między producentami i konsumentami, eliminując wszystkich pośredników. Dla wielu rolników współpraca z kooperatywami ma wymiar nie tylko finansowy, ale też ideologiczny.

Rozważania na temat wspólnej polityki rolnej (WPR) pokazują, że problemów rozwojowych obszarów wiejskich nie rozwiąże sama WPR, lecz potrzebne są zintegrowane działania pozostałych polityk unijnych. $\mathrm{Z}$ kolei zaostrzenie ram polityki klimatyczno-energetycznej UE będzie skutkowało ciągiem przeobrażeń na wsi. Rolnictwo będzie musiało zmierzyć się z podwójnym wyzwaniem - redukcją emisji i jednoczesną adaptacją do zmieniających się warunków gospodarowania, zmianie ulegną również proporcje pełnionych przez wieś funkcji.

Porównując budżet WPR 2014-2020 z budżetem amerykańskiej polityki w ramach Farm Bill 2014-2023, zauważamy, że obie polityki znacząco różnią się priorytetami. W UE obserwujemy poszerzenie obszaru wsparcia z tytułu dostarczania dóbr publicznych przy jednoczesnym znacznym wzroście bezpośredniego wspierania konkretnych kierunków produkcji rolniczej. Z kolei w USA większość budżetu nadal będzie przeznaczana na wsparcie żywnościowe dla konsumentów (m.in. w ramach food stamps). 


\section{Bibliografia}

Bańkowska K. (2015). Pakiet klimatyczno-energetyczny determinantem przeobrażeń obszarów wiejskich. Roczniki Naukowe SERiA, 17 (4), 16-20.

Bańkowska K. (2016). Światowe porozumienie klimatyczne a rozwój obszarów wiejskich. Wieś i Rolnictwo, 1, 87-104.

Bańkowska K., Klimkowski C., Gruda M. (2015). Ocena wybranych elementów unijnej polityki rolnej. Warszawa: Instytut Ekonomiki Rolnictwa i Gospodarki Żywnościowej - Państwowy Instytut Badawczy.

Bańkowska K., Król M. (2014). Wynagradzanie za środowiskowe dobra publiczne dostarczane przez rolnictwo. W: Woźniak M., Pierzchała E. (red.). Dobra publiczne w administracji (s. 215-236). Toruń: Wydawnictwo Adam Marszałek.

Czarnecki A., Kłodziński M., Stanny M. (2015). Przestrzenny wymiar wielofunkcyjności wsi. Typologia gmin według form użytkowania ziemi. W: Hardt Ł., Milczarek-Andrzejewska D. (red.). Ekonomia jest piękna? Księga dedykowana Profesorowi Jerzemu Wilkinowi (s. 305-318). Warszawa: Wydawnictwo Naukowe Scholar.

Drygas M. (2014a). Kierunki reform polityki rolnej UE i USA w perspektywie do 2020 roku. (materiały niepublikowane).

Drygas M. (2014b). Zmiany w rolnictwie USA w świetle Spisu Rolnego 2012. Wieś i Rolnictwo, 4, 99-111.

Drygas M. (2015). Potencjalne skutki dla rolnictwa polskiego umowy o wolnym handlu (TTIP) pomiędzy UE i USA (materiały niepublikowane).

Drygas M., Nurzyńska I. (2015). Zrównoważona intensyfikacja - mit czy realna szansa? W: Hardt Ł., Milczarek-Andrzejewska D. (red.). Ekonomia jest piękna? Księga dedykowana Profesorowi Jerzemu Wilkinowi (s. 336-350). Warszawa: Wydawnictwo Naukowe Scholar.

Dzun W. (2014a). Zmiany strukturalne w sektorze gospodarstw osób prawnych w okresie przed i po akcesyjnym (lata 1996-2010). Zagadnienia Ekonomiki Rolnej, 3, 20-44.

Dzun W. (2014b). Produkcyjne wykorzystanie zasobów ziemi rolnej w gospodarstwach rolnych z uwzględnieniem ich form prawno-organizacyjnych. Wieś $i$ Rolnictwo, 4, 61-82.

Dzun W. (2015a). Gospodarstwa rolne osób prawnych w procesie transformacji systemowej i integracji z UE. Warszawa: Instytut Rozwoju Wsi i Rolnictwa PAN.

Dzun W. (2015b). Wpływ przyspieszenia przemian własnościowych w rolnictwie na zmiany w strukturze prawno-własnościowej i obszarowej gospodarstw rolnych w Polsce. W: Hardt Ł., Milczarek-Andrzejewska D. (red.). Ekonomia jest piękna? Ksiegga dedykowana Profesorowi Jerzemu Wilkinowi (s. 351-368). Warszawa: Wydawnictwo Naukowe Scholar.

Dzun W. (2015c). Wpływ utworzenia i rozdysponowania Zasobu Własności Rolnej SP na strukturę gospodarstw rolnych. Zagadnienia Ekonomiki Rolnej, 3, 48-72.

Dzun W. (2016). Wpływ rozdysponowania Zasobu Własności Rolnej Skarbu Państwa na strukturę gospodarstw rolnych w latach 1996-2010. Zagadnienia Ekonomiki Rolnej, $2,26-51$. 
Francois J., Manchin M., Norberg H., Pindyuk O., Tomberger P. (2013). Reducing Transatlantic Barriers to Trade and Investment: an Economic Assessment. London: Centre for Economic Policy Research (CEPR).

Frenkel I. (2015). Przemiany demograficzne i aktywność ekonomiczna ludności wiejskiej w latach 2010-2013. Wieś i Rolnictwo, 2, 33-62.

Frenkel I. (2016). Prognoza demograficzna Polski do 2050 roku ze szczególnym uwzględnieniem obszarów wiejskich. Wieś i Rolnictwo, 1, 19-58.

Halamska M. (2014a). Struktura społeczna współczesnej polskiej wsi. Zróżnicowanie regionalne. Wieś i Rolnictwo, 1, 81-96.

Halamska M. (2014b). Współczesne rolnictwo rodzinne: polimorficzna rzeczywistość i mity. Wieś i Rolnictwo, 2, 25-46.

Halamska M. (2015a). O rzeczywistych i pozornych funkcjach drobnych gospodarstw (raz jeszcze). W: Hardt Ł., Milczarek-Andrzejewska D. (red.). Ekonomia jest piękna? Księga dedykowana Profesorowi Jerzemu Wilkinowi (s. 383-394). Warszawa: Wydawnictwo Naukowe Scholar.

Halamska M. (2015b). Specyfika rolnictwa rodzinnego w Polsce: ciężar przeszłości i obecne uwarunkowania. Wieś i Rolnictwo, 1, 107-130.

Halamska M. (2016). Struktura społeczno-zawodowa ludności wiejskiej w Polsce i jej przestrzenne zróżnicowanie. Wieś i Rolnictwo, 1, 59-85.

Jasiński J., Michalska S., Śpiewak R. (2014). Rynki zakorzenione - koncepcja uruchomienia mechanizmów lokalnego rozwoju. Wieś i Rolnictwo, 3, 105-124.

Kamiński R. (2014). Sytuacja lokalnych organizacji społecznych w kontekście rozwoju endogennego (materiały niepublikowane).

Kłodziński M. (2014a). Przedsiębiorczość pozarolnicza na wsi w procesie wielofunkcyjnego rozwoju obszarów wiejskich. Wieś i Rolnictwo, 1, 97-112,

Kłodziński M. (2014b). Sektor przedsiębiorczości pozarolniczej w procesie zrównoważonego rozwoju obszarów wiejskich. Roczniki Naukowe SERiA, 16(2), 123-128.

Kłodziński M. (2015a). Kształtowanie się rozwoju przedsiębiorczości wiejskiej na tle ogólnokrajowych i europejskich tendencji wiejskich. Roczniki Naukowe SERiA, 17(3), 175-179.

Kłodziński M. (2015b). Zagrożenia i szanse stojące przed rozwojem sektora przedsiębiorczości wiejskiej. Wieś $i$ Rolnictwo, 2, 125-138

Marsden T., Sonnino R. (2008). Rural development and the regional state: Denying multifunctional agriculture in the UK. Journal of Rural Studies, 24, 422-431

Michalska S. (2015a). Evolution of social roles of rural women in Poland: Facilitating and constraining factors. W: Zajda K., Michalska S. (red.). Young Researchers and the Problems of Polish Rural Areas (s. 83-100). Warszawa: Wydawnictwo Uniwersytetu Łódzkiego, Instytut Rozwoju Wsi i Rolnictwa PAN.

Michalska S. (2015b). Kobiety wiejskie dawniej i dziś - nowe szanse czy nowe ograniczenia? W: Wołk A., Potasińska A. (red.). Nierówności społeczne we wspótczesnym świecie (s. 180-192). Warszawa: Wydawnictwo Uniwersytetu Kardynała Stefana Wyszyńskiego.

Michalska S. (2015c). Tradycyjni aktorzy w nowych rolach - zmiany ról kobiet wiejskich jako przykład zmian społecznych na wsi. W: Podedworna H., Pilichowski A., Knieć W. (red.). Nowi sprawcy zmian społecznych na wsi (s. 129-147). Warszawa: Wydawnictwo SGGW. 
Milczarek-Andrzejewska D., Śpiewak R. (2015). Organizacje rolnicze i ich wpływy na otoczenie - podejście teoretyczne z perspektywy socjologicznej i ekonomicznej. Wieś i Rolnictwo, 4, 67-76.

Milczarek-Andrzejewska D., Zawalińska K. (2015). Konflikty wokół ziemi - czy Wspólna Polityka Rolna może je łagodzić? W: Hardt Ł., Milczarek-Andrzejewska D. (red.). Ekonomia jest piękna? Księga dedykowana Profesorowi Jerzemu Wilkinowi (s. 407-422). Warszawa: Wydawnictwo Naukowe Scholar.

Musiał W., Płonka A., Wojewodzic T. (2015). Problemy przebudowy strukturalnej rozdrobnionego rolnictwa w aspekcie dezagraryzacji produkcyjnej gospodarstw. Roczniki Naukowe SERiA, 17 (5), 179-185.

Musiał W., Wojewodzic T. (2015). Bariery przemian agrarnych w rolnictwie polskim - poszukiwanie rozwiązań innowacyjnych. W: Czyżewski A., Klepacki B. (red.). Problemy rozwoju rolnictwa i gospodarki żywnościowej w pierwszej dekadzie członkostwa Polski w Unii Europejskiej (s. 91-109). Warszawa: Polskie Towarzystwo Ekonomiczne.

Nurzyńska I. (2014a). Nowe koncepcje i instrumenty polityki regionalnej w Unii Europejskiej a rozwój obszarów wiejskich w Polsce. Wieś i Rolnictwo, 4, 27-43.

Nurzyńska I. (2014b). Przemiany struktury gospodarki wiejskiej. W: Nurzyńska I., Poczta W. (red). Polska wieś 2014. Raport o stanie wsi (s. 125-152). Warszawa: Wydawnictwo Naukowe Scholar.

Rosner A., Stanny M. (2014). Monitoring rozwoju obszarów wiejskich. Etap I. Przestrzenne zróżnicowanie poziomu rozwoju społeczno-gospodarczego obszarów wiejskich w 2010 ro$k u$. Warszawa: Fundacja EFRWP, Instytut Rozwoju Wsi i Rolnictwa PAN.

Stanny M. (2014a). Identyfikacja warunków (endogenicznych czynników) rozwoju społeczno-gospodarczego obszarów wiejskich w Polsce. Typologia gmin według struktury zasobów lokalnych (materiały niepublikowane).

Stanny M. (2014b). Wieś, obszar wiejski, ludność wiejska - o problemach z ich definiowaniem. Wielowymiarowe spojrzenie. Wieś $i$ Rolnictwo, 1, 123-138.

Stanny M., Strzelczyk W. (2015). Zróżnicowanie przestrzenne sytuacji dochodowej gmin a rozwój społeczno-gospodarczy obszarów wiejskich w Polsce. Roczniki Naukowe SERiA, 17(4), 301-307.

Szafraniec K. (2014). Chłopi i rolnicy w procesach przekształceń ustrojowych. Analiza dynamiki grupowej. W: Adamski W. (red.). Fenomen „Solidarności” i zmiana ustroju. Polacy 1980-2011 (s. 503-534). Warszawa: Wydawnictwo IFiS PAN.

Szafraniec K. (2015). Rolnicy a pozostali mieszkańcy wsi i miast. Analiza zmian sytuacji życiowej, postaw i orientacji politycznych po 1989 roku. Wieś $i$ Rolnictwo, 2, 63-82.

Śpiewak R. (2014). Alternatywne sieci produkcji, dystrybucji i konsumpcji żywności (AAFN) i różne ich struktury: stare i nowe (materiały niepublikowane).

Śpiewak R., Milczarek-Andrzejewska D., Ciechomska A. (2016). Organizacje rolnicze w Polsce - próba typologii (w druku).

Wasielewski K. (2014). Wiejski rynek pracy - z perspektywy migrantów (materiały niepublikowane).

Zarębski P. (2015). Typy obszarów wiejskich w Polsce ze względu na poziom rozwoju społeczno-gospodarczego i dynamikę przedsiębiorstw. Wieś i Rolnictwo, 3, 63-78. 
Zawalińska K. (2015). Funkcje obszarów wiejskich a ich odporność na kryzysy gospodarcze w Polsce (materiały niepublikowane).

Zawalińska K., Majewski E., Wąs A. (2015). Długookresowe zmiany w dochodach z polskiego rolnictwa na tle krajów UE. Roczniki Naukowe SERiA, 17(6), 346-354.

\title{
Polish Rural Areas Facing Socio-Economic Challenges of the 21st Century in view of Research Conducted in IRWIR PAN in 2014 and 2015
}

\begin{abstract}
This article presents the main conclusions from the research conducted by scientists employed in IRWiR PAN in 2014-2015. The analyses conducted address key economic and social processes taking place in rural areas in recent decades. The article contains selected findings on: territorial structure of the individual farms' sector, changes in demographic structures, the rural labour market, spatial development of rural areas, social changes and institutional and organizational development of the countryside. An important area of research undertaken in IRWiR PAN relates to the evaluation of the Common Agricultural Policy and its comparison with policies implemented in other countries, including Farm Bill in the United States.
\end{abstract}

Key words: rural areas, socio-economic development, agrarian structure, rural population, rural labour market, spatial development, Common Agricultural Policy, Farm Bill. 
